\title{
Hyperbaric oxygen therapy for central retinal artery occlusion: experience in Hong Kong
}

Lai-Ting Yip, MBChB(CUHK), MRCSEd (Ophth), FCOphth(HK), FHKAM (Ophthalmology); Sunny CL Au, MBChB(CUHK), MRCSEd (Ophth), AFCOphth (HK); Callie KL Ko, MBBS(HK), MRCSEd (Ophth), FCOphth(HK), FHKAM (Ophthalmology)

Department of Ophthalmology, Pamela Youde Nethersole Eastern Hospital, Hong Kong

Correspondence and reprint requests:

Dr Lai-Ting Yip, Hong Kong Eye Hospital, 147K Argyle Street, Kowloon, Hong Kong. Email: drfannyyip@gmail.com

\section{Abstract}

Objective: To review medical records of patients who underwent hyperbaric oxygen therapy (HBOT) for central retinal artery occlusion (CRAO).

Methods: Medical records of patients who underwent HBOT for CRAO between November 2018 and December 2019 were reviewed. The first emergency HBOT was at 2.8 atmosphere absolute for 90 minutes with staged decompression. Subsequent sessions were at 2.4 atmosphere absolute twice daily or daily. Patients were followed up daily at the eye clinic. HBOT lasted for 5 days or 10 treatment sessions if there was visual improvement on day 3. Treatments were discontinued if patients had no visual improvement or were unable to tolerate the treatment or experienced major adverse effects, or when the patient was confirmed to not have CRAO.

Results: Of 31 patients who underwent HBOT, 25 with CRAO (17 men, 8 women; aged 44 to 89 years) were included. Mean onset-to-door time was $3.3 \pm 4.2$ hours, and mean onset-to-HBOT time was $13.3 \pm 7.4$ hours. Mean number of HBOT sessions was 7.9 \pm 2.7 . Mean change in visual acuity (VA) was $-0.43 \operatorname{LogMAR}(\mathrm{p}=0.003)$. At the end of treatment, $84 \%$ had VA of 0.1 (1.0 logMAR) or worse and $64 \%$ had VA of finger counting (1.7 logMAR) or worse. No factors were associated with VA improvement including age, onset-to-door time, onset-to-HBOT time, number of HBOT sessions, or pre-HBOT VA.
Conclusion: HBOT for CRAO shows promising visual outcomes. It is important to be aware of the systemic complication of CRAO and provide timely systemic cardiovascular examination for CRAO patients.

Key words: Hyperbaric oxygenation; Retinal artery occlusion

\section{Introduction}

Central retinal artery occlusion (CRAO) is an uncommon but disabling ocular emergency. ${ }^{1}$ The incidence of CRAO has been reported as $<2$ per 100000 population in a study in the United States ${ }^{2}$ and 1.72 per 100000 population in a study in South Korea. ${ }^{3}$ In a large series of 244 patients, ${ }^{4}$ natural outcomes of CRAO were poor: $81 \%$ of patients had final visual acuity (VA) of 0.1 or worse and $61.5 \%$ had final VA of finger counting or worse. With conventional management or without treatment, 38\% had VA improvement, whereas $19 \%$ had improvement in both VA and visual field. In a subgroup of 171 patients with non-arteritic CRAO with no cilioretinal artery sparing, the outcome was worse: $98.4 \%$ had final VA of 0.1 or worse and $78.5 \%$ had final VA of finger counting or worse; only $6 \%$ had improvement in both VA and visual field.

Conventional management modalities of CRAO include ocular massage, intraocular pressure-lowering drugs or techniques (such as glaucoma eyedrops, intravenous or oral Diamox, intravenous mannitol, and anterior chamber paracentesis, and rebreathing into a bag to increase carbon dioxide concentration that causes vasodilatation). Newer treatment modalities include intravenous thrombolysis with tissue plasminogen activator ${ }^{5-7}$ and intra-retinal arterial 
cannulation. ${ }^{8}$ Nonetheless, there is no consensus on the optimal therapy for CRAO., ${ }^{4-12}$

In 2008, the Undersea and Hyperbaric Medical Society approved the use of hyperbaric oxygen therapy (HBOT) for CRAO.$^{13}$ The rationale is to supply oxygen to the retina through choroidal circulation by diffusion. Under normal conditions, blood supply to the inner two-third of retina is from the central retinal artery, whereas the outer one-third is from the choroidal circulation by diffusion. Under normoxic conditions, about $60 \%$ of retinal oxygen supply comes from choroidal circulation. Under hyperoxic conditions, choroid is capable of supplying $100 \%$ oxygen needed by the retina. ${ }^{14}$ Other proposed rationales for the use of HBOT in CRAO are related to hyperbaric oxygen effect on edema reduction and its ability to blunt ischemia-reperfusion injury after recanalization occurs..$^{15}$

In September 2018, the Pamela Youde Nethersole Eastern Hospital set up the first hospital-based HBOT center in Hong Kong. HBOT was first used for life-threatening cases including decompression sickness, carbon monoxide poisoning, and necrotizing fasciitis. In November 2018, HBOT was used to treat patients with other indications such as CRAO, osteomyelitis, delayed radiation injuries, and idiopathic sudden sensorineural hearing loss. The HBOT chamber (Haux-Starmed-Quadro 3300-2300) is divided into 3 sub-chambers with individual pressure control. Patients wear oxygen hoods with $100 \%$ oxygen, and the entire subchamber is pressurized to a desired pressure level.

\section{Methods}

Medical records of patients who underwent HBOT for CRAO between November 2018 and December 2019 were reviewed. The diagnosis of CRAO was made by an ophthalmologist, and patients with the symptom onset-todoor time of $<6$ hours were referred to our center for HBOT (Figure 1). Patients with the symptom onset-to-door time of $>6$ hours were treated with HBOT depending on individual case conditions (such as those with only eye) and manpower availability. Those with CRAO of iatrogenic causes such as filler-related CRAO, branch retinal arterial occlusion, cilioretinal artery occlusion, or any absolute contraindication to HBOT such as untreated pneumothorax were excluded. Emergency treatments such as ocular massage, anterior chamber paracentesis, rebreathing bag, and Diamox were given by the referring ophthalmologists before transfer.

Baseline ophthalmological assessments included VA, intraocular pressure, pupillary reaction, anterior segment and dilated fundal examination. VA measured in Snellen decimals was converted to logarithm of minimal angle of resolution (LogMAR): finger counting = $1.7 \log$ MAR, hand movement $=2.0 \log \mathrm{MAR}$, light perception = $2.3 \log \mathrm{MAR}$, and no light perception $=3.0 \log$ MAR.${ }^{16}$ Fundal fluorescein angiography as a gold standard for diagnosis was performed on the next available working day. Patients were followed up at eye clinic daily for VA, intraocular pressure, dilated fundal examination.

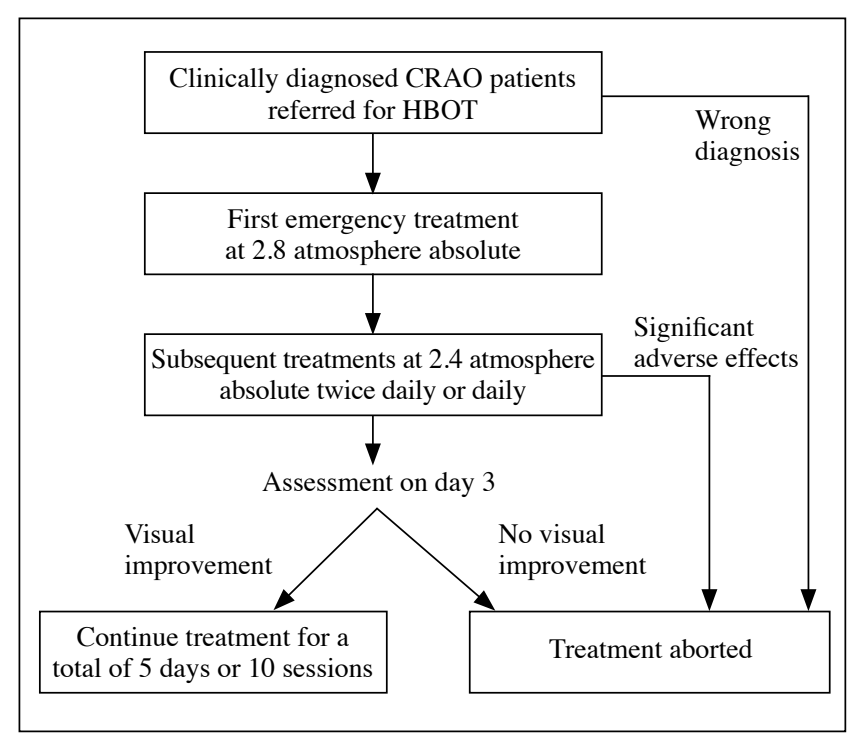

Figure 1. Protocol of hyperbaric oxygen therapy (HBOT) for central retinal artery occlusion (CRAO)

Blood tests for cardiovascular risk factors and chest radiography were performed at the emergency department before HBOT to rule out any contraindication for treatment including pneumothorax. The first emergency HBOT was at 2.8 atmosphere absolute for 90 minutes with staged decompression. Subsequent sessions were at 2.4 atmosphere absolute twice daily or daily based on the US Navy Treatment Table 9. Patients were followed up daily at the eye clinic. HBOT would last for a total of 5 days or 10 treatment sessions if there was visual improvement on day 3 . Treatments were discontinued if patients had no visual improvement or were unable to tolerate the treatment or experienced major adverse effects, or when the patient was confirmed to not have CRAO. Patients were subsequently referred to the medical department for detailed assessment to determine whether further investigation such as neuroimaging was necessary.

Statistical analysis was performed using SPSS (version 25, IBM, USA). To determine factors associated with VA improvement, Fisher's exact test was used for categorical variables and t-test was used for continuous variables.

\section{Results}

Of 31 patients who underwent HBOT, six were non-CRAO cases including branch retinal arterial occlusion $(n=3)$, central serous choroioretinopathy $(n=1)$, orbital apex tumour $(n=1)$, and retrobulbar optic neuritis $(n=1)$, and HBOT was terminated. The remaining 17 male and 8 female patients with CRAO were aged 44 to 89 years, with the mean onsetto-door time of $3.3 \pm 4.2$ (range, $0-16$ ) hours, and the mean onset-to-HBOT time of 13.3 \pm 7.4 (range, 4.4-32.2) hours. $68 \%(17 / 25)$ were treated within 12 hours of symptom onset. The mean number of HBOT sessions was 7.9 2.7 (range, 3-14) [Table]. 


\begin{tabular}{|c|c|c|c|c|c|c|c|c|c|c|c|}
\hline \multirow{2}{*}{$\begin{array}{l}\text { Pa- } \\
\text { tient }\end{array}$} & \multirow{2}{*}{$\begin{array}{l}\text { Sex/ } \\
\text { age, } y\end{array}$} & \multirow[t]{2}{*}{ Comorbidity } & \multirow{2}{*}{$\begin{array}{l}\text { Affected } \\
\text { eye }\end{array}$} & \multirow{2}{*}{$\begin{array}{l}\text { Treatment before } \\
\text { HBOT }\end{array}$} & \multirow{2}{*}{$\begin{array}{l}\text { Relative } \\
\text { afferent } \\
\text { pupillary } \\
\text { defect }\end{array}$} & \multirow{2}{*}{$\begin{array}{l}\text { Cherry } \\
\text { red } \\
\text { spot }\end{array}$} & \multirow{2}{*}{$\begin{array}{l}\text { Onset- } \\
\text { to- } \\
\text { door } \\
\text { time, } \\
\text { hours }\end{array}$} & \multirow{2}{*}{$\begin{array}{l}\text { Onset- } \\
\text { to- } \\
\text { HBOT } \\
\text { time, } \\
\text { hours }\end{array}$} & \multirow{2}{*}{$\begin{array}{l}\text { No. of } \\
\text { HBOT } \\
\text { sessions }\end{array}$} & \multicolumn{2}{|c|}{ Visual acuity } \\
\hline & & & & & & & & & & $\begin{array}{l}\text { Before } \\
\text { treatment }\end{array}$ & $\begin{array}{l}\text { After } 1 \\
\text { week }\end{array}$ \\
\hline 1 & $\mathrm{M} / 64$ & $\begin{array}{l}\text { Diabetes mellitus, } \\
\text { hypertension, hyperlipidemia }\end{array}$ & Right & Normobaric oxygen & Yes & Yes & 16 & 19.7 & 10 & $\begin{array}{l}\text { Hand } \\
\text { movement }\end{array}$ & $\begin{array}{l}\text { Hand } \\
\text { movement }\end{array}$ \\
\hline 2 & $\mathrm{~F} / 80$ & $\begin{array}{l}\text { Diabetes mellitus, } \\
\text { hypertension, ischemic heart } \\
\text { disease, old cerebrovascular } \\
\text { accident }\end{array}$ & Left & $\begin{array}{l}\text { Rebreathing bag, ocular } \\
\text { massage }\end{array}$ & $\begin{array}{l}\text { No (fellow } \\
\text { eye branch } \\
\text { retinal arterial } \\
\text { occlusion) }\end{array}$ & Yes & 2 & 8 & 14 & $\begin{array}{l}\text { Hand } \\
\text { movement }\end{array}$ & 0.222 \\
\hline 3 & $\mathrm{M} / 59$ & $\begin{array}{l}\text { Hypertension, hyperlipidemia, } \\
\text { atrial fibrillation }\end{array}$ & Left & $\begin{array}{l}\text { Rebreathing bag, ocular } \\
\text { massage, diamox } 250 \mathrm{mg} \\
\text { po, alphagan P }\end{array}$ & Yes & Yes & 2 & 10 & 10 & $\begin{array}{l}\text { Light } \\
\text { perception }\end{array}$ & $\begin{array}{l}\text { Finger } \\
\text { counting }\end{array}$ \\
\hline 4 & $\mathrm{M} / 74$ & $\begin{array}{l}\text { Hypertension, hyplipidemia, } \\
\text { atrial fibrillation, ischemic } \\
\text { heart disease }\end{array}$ & Left & $\begin{array}{l}\text { Rebreathing bag, ocular } \\
\text { massage, diamox } 250 \mathrm{mg} \\
\text { po, alphagan P }\end{array}$ & Yes & Yes & 1.5 & 10 & 10 & $\begin{array}{l}\text { Hand } \\
\text { movement }\end{array}$ & $\begin{array}{l}\text { Finger } \\
\text { counting }\end{array}$ \\
\hline 5 & $\mathrm{M} / 51$ & $\begin{array}{l}\text { Newly diagnosed } \\
\text { hypertension, hyperlipidemia }\end{array}$ & Right & $\begin{array}{l}\text { Rebreathing bag, ocular } \\
\text { massage, diamox } 500 \mathrm{mg} \\
\text { IV }\end{array}$ & Yes & No & 0.5 & 4.4 & 10 & $\begin{array}{l}\text { Hand } \\
\text { movement }\end{array}$ & $\begin{array}{l}\text { Finger } \\
\text { counting }\end{array}$ \\
\hline 6 & $\mathrm{~F} / 48$ & Good & Left & $\begin{array}{l}\text { Rebreathing bag, ocular } \\
\text { massage }\end{array}$ & Yes & Yes & 3 & 8.4 & 10 & $\begin{array}{l}\text { Hand } \\
\text { movement }\end{array}$ & 0.7 \\
\hline 7 & $\mathrm{M} / 82$ & $\begin{array}{l}\text { Diabetes mellitus, } \\
\text { hypertension, hyperlipidemia }\end{array}$ & Left & Nil & Yes & Yes & 5 & 16 & 9 & $\begin{array}{l}\text { Light } \\
\text { perception }\end{array}$ & $\begin{array}{l}\text { Hand } \\
\text { movement }\end{array}$ \\
\hline 8 & $\mathrm{M} / 68$ & $\begin{array}{l}\text { Impaired fasting glucose, } \\
\text { hyperlipidemia, old } \\
\text { cerebrovascular accident }\end{array}$ & Right & $\begin{array}{l}\text { Rebreathing bag, ocular } \\
\text { massage, diamox } 500 \mathrm{mg} \\
\text { po, timolol }\end{array}$ & Yes & Yes & 0.5 & 8 & 9 & $\begin{array}{l}\text { Light } \\
\text { perception }\end{array}$ & $\begin{array}{l}\text { Finger } \\
\text { counting }\end{array}$ \\
\hline 9 & $\mathrm{~F} / 74$ & $\begin{array}{l}\text { Diabetes mellitus, } \\
\text { hypertension, hyperlipidemia }\end{array}$ & Left & $\begin{array}{l}\text { Ocular massage, diamox } \\
250 \mathrm{mg} \text { po }\end{array}$ & Yes & Yes & 5 & 9 & 9 & $\begin{array}{l}\text { Hand } \\
\text { movement }\end{array}$ & $\begin{array}{l}\text { Finger } \\
\text { counting }\end{array}$ \\
\hline 10 & $\mathrm{M} / 45$ & $\begin{array}{l}\text { Newly diagnosed hypertension } \\
\text { and hyperlipidemia }\end{array}$ & Right & $\begin{array}{l}\text { Diamox } 500 \mathrm{mg} \mathrm{IV} \text {, } \\
\text { timolol }\end{array}$ & Yes & Yes & 0.75 & 8.6 & 3 & $\begin{array}{l}\text { Hand } \\
\text { movement }\end{array}$ & $\begin{array}{l}\text { Hand } \\
\text { movement }\end{array}$ \\
\hline 11 & $F / 64$ & Good & Left & $\begin{array}{l}\text { Diamox } 500 \mathrm{mg} \text { IV, } \\
\text { timolol }\end{array}$ & Yes & Yes & 0 & 26.9 & 8 & $3 / 60$ & 0.3 \\
\hline 12 & $F / 76$ & $\begin{array}{l}\text { Diabetes mellitus, } \\
\text { hypertension, hyperlipidemia }\end{array}$ & Right & ocular massage, timolol & Yes & Yes & 1.5 & 8 & 3 & $1 / 60$ & 0.017 \\
\hline 13 & $\mathrm{M} / 70$ & $\begin{array}{l}\text { Diabetes mellitus, } \\
\text { hypertension, hyperlipidemia, } \\
\text { ischemic heart disease }\end{array}$ & Left & Nil & Yes & Yes & 16 & 18.6 & 5 & $\begin{array}{l}\text { Hand } \\
\text { movement }\end{array}$ & 0.008 \\
\hline 14 & $\mathrm{M} / 70$ & $\begin{array}{l}\text { Newly diagnosed } \\
\text { hypertension, hyperlipidemia }\end{array}$ & Right & Nil & Yes & Yes & 0.5 & 8.2 & 8 & $\begin{array}{l}\text { Light } \\
\text { perception }\end{array}$ & 0.017 \\
\hline 15 & $\mathrm{M} / 61$ & $\begin{array}{l}\text { hypertension, hyperlipidemia, } \\
\text { old cerebrovascular accident }\end{array}$ & Left & $\begin{array}{l}\text { Diamox } 500 \mathrm{mg} I \mathrm{~V}, \\
\text { xalacom }\end{array}$ & Yes & Yes & 1.3 & 18.2 & 10 & $\begin{array}{l}\text { Finger } \\
\text { counting }\end{array}$ & $\begin{array}{l}\text { Finger } \\
\text { counting }\end{array}$ \\
\hline 16 & $\mathrm{M} / 82$ & $\begin{array}{l}\text { Diabetes mellitus, } \\
\text { hypertension, hyperlipidemia }\end{array}$ & Right & $\begin{array}{l}\text { Ocular massage, diamox } \\
500 \mathrm{mg} \text { IV, timolol }\end{array}$ & Yes & Yes & 0.5 & 7 & 7 & $\begin{array}{l}\text { Hand } \\
\text { movement }\end{array}$ & $\begin{array}{l}\text { Finger } \\
\text { counting }\end{array}$ \\
\hline 17 & $\mathrm{M} / 75$ & $\begin{array}{l}\text { Diabetes mellitus, } \\
\text { hypertension, hyperlipidemia, } \\
\text { old cerebrovascular accident }\end{array}$ & Right & $\begin{array}{l}\text { Rebreathing bag, ocular } \\
\text { massage, timolol }\end{array}$ & Yes & Yes & 2 & 8.8 & 7 & $\begin{array}{l}\text { Hand } \\
\text { movement }\end{array}$ & $\begin{array}{l}\text { Finger } \\
\text { counting }\end{array}$ \\
\hline 18 & $\mathrm{M} / 74$ & Good & Left & $\begin{array}{l}\text { Rebreathing bag, ocular } \\
\text { massage, diamox } 500 \mathrm{mg} \\
\text { IV, timolol }\end{array}$ & Yes & Yes & 5.5 & 19.7 & 8 & $\begin{array}{l}\text { Light } \\
\text { perception }\end{array}$ & $\begin{array}{l}\text { Hand } \\
\text { movement }\end{array}$ \\
\hline 19 & $\mathrm{~F} / 50$ & $\begin{array}{l}\text { Impaired fasting glucose, } \\
\text { newly diagnosed hypertension }\end{array}$ & Left & $\begin{array}{l}\text { Rebreathing bag, ocular } \\
\text { massage, diamox } 500 \mathrm{mg} \\
\text { IV, timolol }\end{array}$ & No & No & 4 & 28.8 & 10 & $\begin{array}{l}\text { Finger } \\
\text { count }\end{array}$ & 0.8 \\
\hline 20 & $\mathrm{M} / 56$ & $\begin{array}{l}\text { Diabetes mellitus, } \\
\text { hypertension }\end{array}$ & Right & $\begin{array}{l}\text { Ocular massage, diamox } \\
500 \mathrm{mg} \text { IV, timolol }\end{array}$ & $\begin{array}{l}\text { No (fellow } \\
\text { eye no light } \\
\text { perception) }\end{array}$ & Yes & 2.3 & 9.5 & 10 & $\begin{array}{l}\text { No light } \\
\text { perception }\end{array}$ & $\begin{array}{l}\text { No light } \\
\text { perception }\end{array}$ \\
\hline 21 & $\mathrm{M} / 70$ & $\begin{array}{l}\text { Hyperlipidemia, old } \\
\text { cerebrovascular accident }\end{array}$ & Left & $\begin{array}{l}\text { Rebreathing bag, ocular } \\
\text { massage }\end{array}$ & Yes & Yes & 1.25 & 8.6 & 7 & $\begin{array}{l}\text { Hand } \\
\text { movement }\end{array}$ & $\begin{array}{l}\text { Hand } \\
\text { movement }\end{array}$ \\
\hline 22 & $\mathrm{M} / 73$ & Hypertension, carotid stenosis & Left & $\begin{array}{l}\text { Rebreathing bag, ocular } \\
\text { massage }\end{array}$ & Yes & Yes & 2 & 10.9 & 5 & $\begin{array}{l}\text { Finger } \\
\text { counting }\end{array}$ & $\begin{array}{l}\text { Finger } \\
\text { counting }\end{array}$ \\
\hline 23 & $\mathrm{~F} / 44$ & Good & Left & $\begin{array}{l}\text { Rebreathing bag, diamox } \\
500 \mathrm{mg} \text { IV }\end{array}$ & Yes & Yes & 4.8 & 12 & 5 & $\begin{array}{l}\text { Hand } \\
\text { movement }\end{array}$ & 0.7 \\
\hline 24 & $\mathrm{~F} / 89$ & Hypertension & Right & Nil & Yes & Yes & 0.7 & 32.2 & 4 & $\begin{array}{l}\text { Hand } \\
\text { movement }\end{array}$ & $\begin{array}{l}\text { Finger } \\
\text { counting }\end{array}$ \\
\hline 25 & $\mathrm{M} / 69$ & Good & Left & Nil & Yes & Yes & 5 & 12 & 6 & $\begin{array}{l}\text { No light } \\
\text { perception }\end{array}$ & $\begin{array}{l}\text { No light } \\
\text { perception }\end{array}$ \\
\hline
\end{tabular}


At presentation, 92\% (23/25) had VA of finger counting or worse. The mean LogMAR was 2.02 (range, 1.3-3.0) and the median was 2.0 (equivalent to hand movement). $88 \%$ (22/25) had relative afferent pupillary defect on the diseased eye, and $92 \%(23 / 25)$ had cherry red spot on fundal examination (Figure 2).

$84 \%$ (21/25) had known cardiovascular risk factors including diabetes, hypertension, or hyperlipidemia. $20 \%(5 / 25)$ were not prescribed with long-term aspirin after having CRAO.

Seven patients required additional procedures such as myringotomy $(\mathrm{n}=4)$ or otovent $(\mathrm{n}=3)$ for pressure equalization. Two patients had early termination of treatment owing to difficulty in pressure equalization and refusal of myringotomy. The first one developed mild tinnitus during the eighth session. The second patient developed otalgia with suspected hemotypanum after four sessions.
The mean VA change was $-0.43 \operatorname{LogMAR}(\mathrm{p}=0.003) .68 \%$ $(17 / 25)$ had a measurable VA improvement (Figure 3). At the end of treatment, $84 \%(21 / 25)$ had VA of 0.1 (1.0 logMAR) or worse and $64 \%(16 / 25)$ had VA of finger counting (1.7 logMAR) or worse. Among nine patients who remained to be followed up in our center, the same VA was maintained after 1 week to 20 months.

$44 \%(11 / 25)$ received neuroimaging to exclude stroke within 1 week of CRAO and 56\% (14/25) within 2 months. $68 \%$ $(17 / 25)$ were treated for cardiovascular risk factor within 2 weeks. 96\% (24/25) had regular medical assessment after CRAO; one patient was lost to follow-up. One patient developed acute stroke with an acute infarct over the right middle cerebellar peduncle after 3 sessions of HBOT. The patient was admitted to the acute stroke unit for management, and HBOT was terminated. One patient had a fall and subdural hemorrhage 11 months after CRAO; the subdural

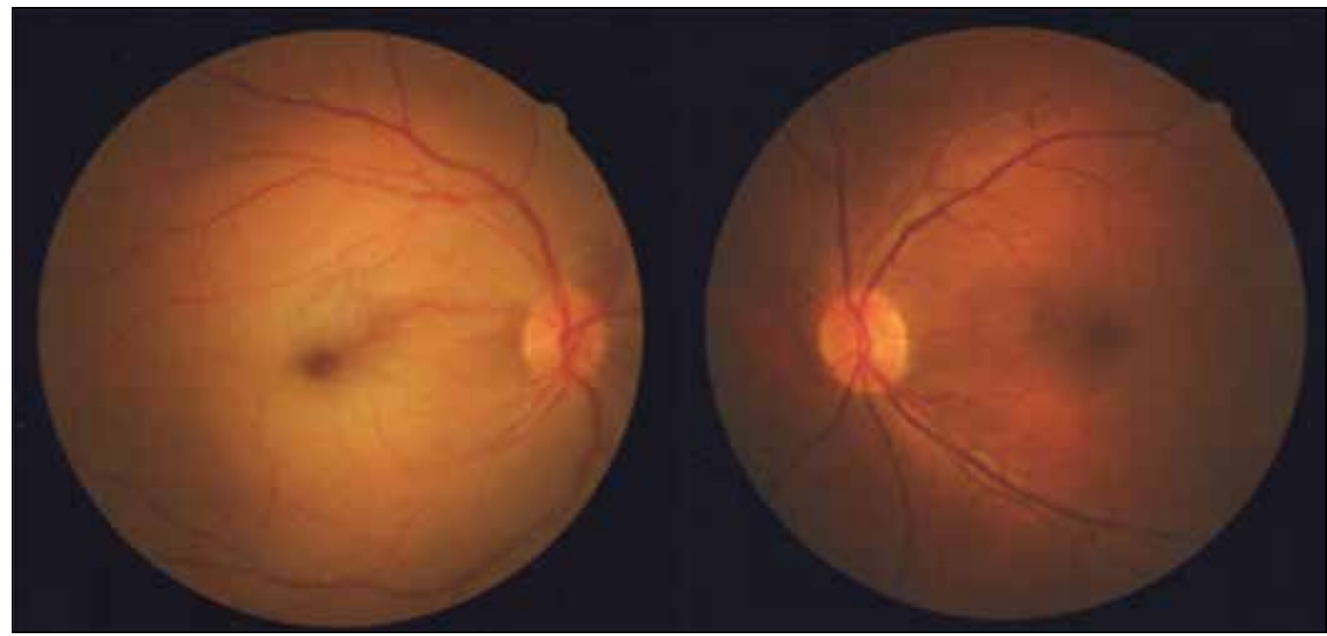

Figure 2. Fundus photos of patient 1 showing a cherry red spot of the right eye.

\section{D2 (Still on HBOT)}

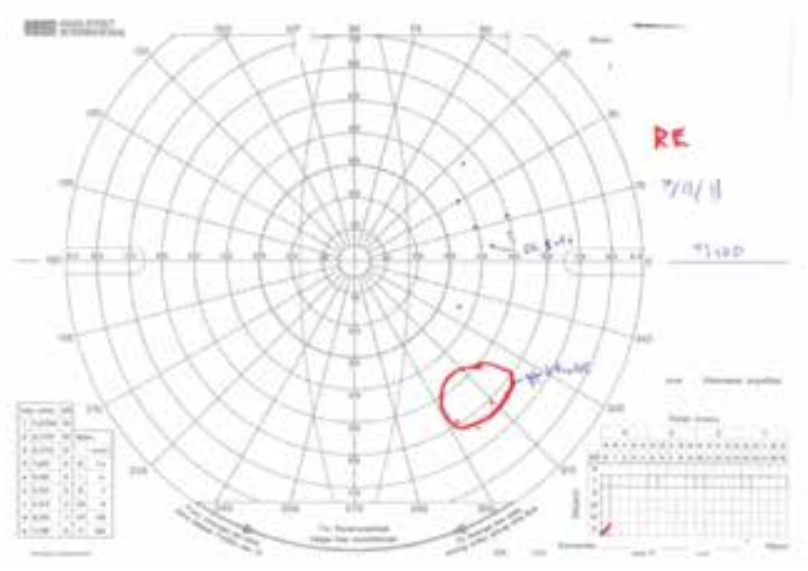

\section{D10 (Finished)}

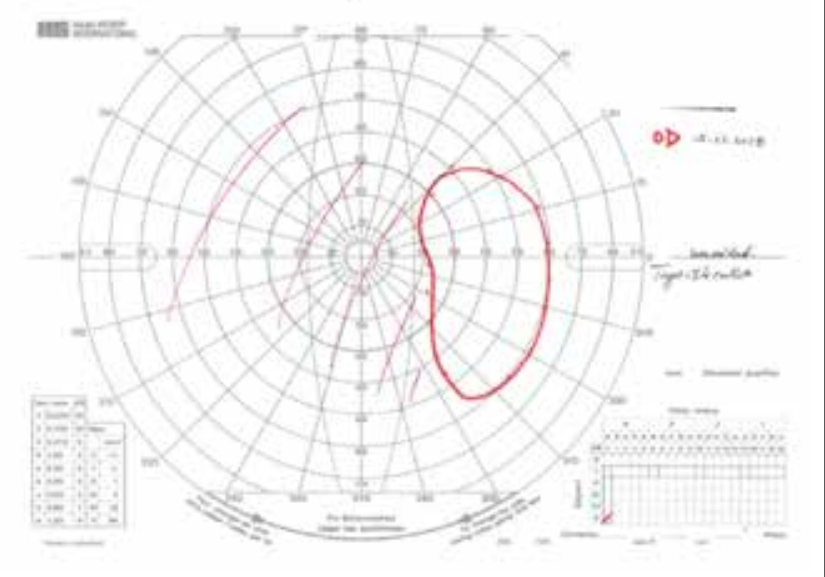

Figure 3. Goldmann visual field of patient 1 on days 2 and 10 of hyperbaric oxygen therapy (HBOT) showing vision improvement 
hemorrhage may have been related to the use of aspirin and dipyridamole. $92 \%$ (23/25) did not have any cerebrovascular events after CRAO.

No factors were associated with VA improvement including age $(\mathrm{p}=0.46)$, onset-to-door time $(\mathrm{p}=0.77)$, onset-to-HBOT time $(p=0.46)$, number of HBOT sessions $(p=0.20)$, or pre-HBOT VA $(\mathrm{p}=0.95)$. Nor these factors associated with VA improvement of $>1$ line, with $p$ values of $0.15,0.59,0.40$, $0.28,0.14$, respectively.

\section{Discussion}

Favorable outcomes of HBOT for CRAO have been reported. In 476 patients with HBOT, $306(65 \%)$ patients experienced vision improvement. ${ }^{17}$ In our case series, $68 \%$ had appreciable VA improvement, compared to $38 \%$ based on the natural history of CRAO. 84\% had final VA of 0.1 or worse and $64 \%$ had final VA of finger counting or worse, compared with $98.4 \%$ and $78.5 \%$, respectively, based on the natural history of CRAO. ${ }^{4}$

Central scotoma is the most common visual defect in CRAO, ${ }^{4}$ because the macula region is the thickest part of the retina. When circulation in the central retinal artery restores, the retinal capillaries in the central, thickest part of the macula region do not refill because of compression by the surrounding swollen superficial retinal tissue. This results in the 'no re-flow phenomenon' and consequently permanent ganglion cell death in the non-perfused retina. ${ }^{18-20}$ In addition, oxygen supply and nutrition from the choroidal vascular bed to the thinner peripheral retina enable longer survival time and maintenance of the peripheral visual field. Therefore, VA measurement alone may not be able to capture all the visual improvements in patients with CRAO. Visual field may improve without a measurable improvement in VA owing to the central scotoma. However, manpower constraints forbid performance of formal visual field tests on all patients before and after treatment.

The rationale for HBOT in CRAO is to support retina's oxygen demand while natural recanalization of the central retinal artery occurs, which is usually present within 72 hours. ${ }^{21}$ In our case series, if patients had no visual improvement after 3 days, it was assumed that the chance of natural recanalization was low and treatment was discontinued. If there was visual improvement, HBOT was extended to after recanalization. In patient 2, treatment was extended to 14 sessions until VA stabilized when there was deterioration of vision after 10 sessions. We hypothesized that recanalization was not established or was partial after 10 sessions and thus VA dropped when there was no oxygen support to the retina by the HBOT. Similar treatment protocol to resume HBOT when patients experience vision drop is also advocated. ${ }^{17}$

There is no consensus on the optimal treatment protocol of HBOT for CRAO. One study suggests titration of oxygen pressure and treatment duration based on vision improvements. ${ }^{17}$ The Henneipin County Medical Center uses standard treatment pressure for all patients with CRAO, ${ }^{22}$ as does our center. Protocols involving titrating treatment pressure for individual patients may be difficult to follow when there are only three individual chambers in our center and patients with different indications are treated at the same time. Manpower and chamber availability should also be considered.

Unlike one study that reported significant correlation between onset-to-HBOT time and visual outcome, ${ }^{22}$ no such correlation was identified in our case series. This was likely due to the inclusion of patients with shorter onset-to-HBOT time only and the small sample size. Blood flow is usually re-established via recanalization. However, if ischemia and hypoxia result in cell death and necrosis in the inner layers of the retina, vision may not return when blood flow is re-established. ${ }^{23}$ There is a threshold of time beyond which ischemic tissue can no longer recover from a hypoxic event, even if reperfusion occurs. ${ }^{14}$ The retina can only survive 90 to 100 minutes of ischemia prior to permanent damage..$^{24,25}$ Visual recovery beyond this timeframe has been reported, potentially owing to incomplete occlusion, an intact cilioretinal artery, or collateral flow. In CRAO, some residual retinal blood flow has been detected by fundal fluorescein angiography. ${ }^{26,27}$ The shorter the treatment delay, the higher the likelihood of recovering the ischemic retina. ${ }^{14,27,28}$ It is important to start the treatment early enough before permanent damage occurs and continue HBOT long enough until natural recanalization occurs. Patients treated within 12 hours of symptom onset achieve greatest improvement in VA. ${ }^{22}$ We aimed to perform HBOT within 12 hours for those with the onset-to-door time of $<6$ hours

HBOT is generally safe and well tolerated. Most of its adverse effects are mild and reversible. Middle ear trauma is the most common adverse effect, with an incidence of around $2 \% .{ }^{29}$ It can be prevented by teaching the patients autoinflation techniques or by placement of tympanostomy tubes. In our case series, only one patient developed suspected hemotypanum. Other reported complications of HBOT include sinus barotrauma, ${ }^{29}$ seizure secondary to toxicity to the central nervous system, ${ }^{30,31}$ pulmonary barotrauma, pulmonary oxygen toxicity, ${ }^{32}$ claustrophobia, and chamber fire. ${ }^{33}$ Reported ocular adverse effects include visual field narrowing and eyelid twitching. Alteration in refraction secondary to HBOT remains controversial. ${ }^{29,34-36}$ Therefore, it is advisable to postpone all keratorefractive surgeries until after HBOT. Increased nuclear cataract formation secondary to oxidative stress in lens protein has been reported, ${ }^{36}$ as has a case of early onset of neovascularization. ${ }^{37}$ It was hypothesized that ischemic phase was prolonged by the improvement in the retinal oxygen saturation, thus enhancing vascular endothelial growth factor release and potentially worsening choroidal neovascularization.

CRAO has significant systemic implications. It increases the risk of stroke and acute myocardial infarction, with an incidence of $44.51 \%$ within 7 days and $14 \%$ within 30 days. $^{3}$ 
CRAO also reduces life expectancy; the life expectancy was 15.4 years in patients with no CRAO and 5.5 years in patients with CRAO. In a Korean study, only one-third of ophthalmologists transferred patients with CRAO to the emergency department for immediate evaluation. Despite being a thromboembolic vascular event in most cases, CRAO is usually not handled in the same manner as a thromboembolic stroke. In a study, $32 \%$ of patients with CRAO showed acute or subacute brain infarct on magnetic resonance imaging. ${ }^{38}$ One of the 58 patients with CRAO had an acute thromboembolic stroke 8 days after CRAO. In our case series, a 45-year-old man (patient 10) with right CRAO experienced vertigo and dizziness after 3 treatment sessions. He was newly diagnosed with hypertension and hyperlipidemia. Urgent neuroimaging revealed acute infarct over the right middle cerebellar peduncle and the patient was admitted to the acute stroke unit, and treatment was terminated. Fortunately, the patient was able to recover from the stroke and to walk unaided. This case highlights the importance of awareness of the increased stroke risk in patients with CRAO. Timely workup and control of cardiovascular risk factors are essential for all CRAO patients.

Limitations of our case series are the small sample size and relatively short follow-up. Studies with a larger sample size and longer follow-up are warranted to determine the efficacy and safety of HBOT for CRAO.

\section{Conclusion}

HBOT for CRAO shows promising visual outcomes. It is important to be aware of the systemic complication of CRAO

\section{References}

1. von Graefe A. Ueber Embolie der Arteria centralis retinae als Urasche plötzlicher Erblindung. Archiv fur Ophthalmologie 1859;5:136-57. crossref

2. Leavitt JA, Larson TA, Hodge DO, Gullerud RE. The incidence of central retinal artery occlusion in Olmsted County, Minnesota. Am J Ophthalmol 2011;152:820-3. e2. Crossref

3. Park SJ, Choi NK, Yang BR, et al. Risk and risk periods for stroke and acute myocardial infarction in patients with central retinal artery occlusion. Ophthalmology 2015;122:2336-43. $e 2$. Crossref

4. Hayreh SS, Zimmerman MB. Central retinal artery occlusion: visual outcome. Am J Ophthalmol 2005;140:376-91. Crossref

5. Weber J, Remonda L, Mattle HP, et al. Selective intra-arterial fibrinolysis of acute central retinal artery occlusion. Stroke 1998;29:2076-9. Crossref

6. Rumelt $S$, Dorenboim $Y$, Rehang U. Aggressive systematic treatment for central retinal artery occlusion. Am J Ophthalmol 1999;128:733-8. Crossref

7. Petterson JA, Hill MD, Demchuk AM, et al. Intra-arterial thrombolysis for retinal artery occlusion: the Calgary experience. Can J Neurol Sci 2005;32:507-11. Crossref and provide timely systemic cardiovascular examination for CRAO patients.

\section{Author contributions}

\section{Concept or design: LTY, CKLK}

Acquisition of data: LTY

Analysis or interpretation of data: LTY, SCLA

Drafting of the article: LTY, SCLA

Critical revision for important intellectual content: LTY, CKLK

All authors had full access to the data, contributed to the study, approved the final version for publication, and take responsibility for its accuracy and integrity.

\section{Conflicts of interest}

As an editor of the Journal, CKL Ko was not involved in the peer review process for this article. Other authors have disclosed no conflicts of interest.

\section{Funding/support}

This research received no specific grant from any funding agency in the public, commercial, or not-for-profit sectors.

\section{Ethics approval}

This study was approved by the Hong Kong East Cluster Research Ethics Committee (reference: HKECREC-2020-11). The patients provided written informed consent for all treatments and procedures.
8. Kadonosono K, Yamane S, Inoue M, Yamakawa T, Uchio E. Intra-retinal arterial cannulation using a microneedle for central retinal artery occlusion. Sci Rep 2018;8:1360. Crossref

9. Atebara NH, Brown GC, Cater J. Efficacy of anterior chamber paracentesis and carbogen in treating acute nonarteritis central retinal artery occlusion. Ophthalmology 1995;102:2029-35. Crossref

10. Mueller AJ, Neubauer AS, Schaller U, Kampik A; European Assessment Group for Lysis in the Eye. Evaluation of minimally invasive therapies and rationale for a prospective randomized trial to evaluate selective intra-arterial lysis for clinically complete central retinal artery occlusion. Arch Ophthalmol 2003;121:1377-81. Crossref

11. Rudkin AK, Lee AW, Aldrich E, Miller NR, Chen CS. Clinical characteristics and outcome of current standard management of central retinal artery occlusion. Clin Exp Ophthalmol 2010;38:496-501. Crossref

12. Fraser $S$, Siriwardena D. Interventions for acute non-arteritic central retinal artery occlusion. Cochrane Database Syst Rev 2002;1:CD001989. Crossref

13. Lindell $K$ Weaver MD. Undersea and Hyperbaric Medical Society. Hyperbaric Oxygen Therapy Indications, 13th Ed.

14. Li HK, Dejean BJ, Tang RA. Reversal of visual loss with hyperbaric oxygen treatment in a patient with Susac syndrome. 
Ophthalmology 1996;103:2091-8. Crossref

15. Buras JA, Garcia-Covarrubias L. Ischemia-reperfusion injury and hyperbaric oxygen therapy. Basic mechanisms and clinical studies. In: Neuman TS, Thom SR, editors. Physiology and Medicine of Hyperbaric Oxygen Therapy. 1st ed. Philadelphia: Saunders Elsevier; 2008. Crossref

16. Lange C, Feltgen N, Junker B, Schulze-Bonsel K, Bach M. Resolving the clinical acuity categories 'hand motion' and 'counting fingers' using the Freiburg Visual Acuity Test (FrACT). Graefes Arch Clin Exp Ophthalmol 2009;247:13742. Crossref

17. Murphy-Lavoie H, Butler F, Hagan C. Central retinal artery occlusion treated with oxygen: a literature review and treatment algorithm. Undersea Hyperb Med 2012;39:94353.

18. Hayreh SS, Zimmerman MB, Kimura A, Sanon A. Central retinal arterial occlusion. Retinal survival time. Exp Eye Res 2004;78:723-36. Crossref

19. Hayreh SS, Weingeist TA. Experimental occlusion of the central artery of the retina. I. Ophthalmoscopic and fluorescein funds angiographic studies. Br J Ophthalmol 1980;64:896912. Crossref

20. Hayreh SS. So-called "central retinal vein occlusion". I. Pathogenesis, terminology, clinical features. Ophthalmologica 1976;172:1-13. Crossref

21. Rumelt S, Brown GC. Update on treatment of retinal arterial occlusions. Curr Opin Ophthalmol 2003;14:139-41. Crossref

22. Masters TC, Westgard BC, Hendriksen SM, et al. Case series of hyperbaric oxygen therapy for central retinal artery occlusion. Retin Cases Brief Rep 2019. Crossref

23. Mangat HS. Retinal artery occlusion. Surv Ophthalmol 1995;40:145-56. Crossref

24. Brown GC, Shields JA. Cilioretinal arteries and retinal arterial occlusion. Arch Ophthalmol 1979;97:84-92. Crossref

25. Hayreh SS, Kolder HE, Weingeist TA. Central retinal artery occlusion and retinal tolerance time. Ophthalmology 1980;87:75-8. Crossref

26. David NJ, Norton EW, Gass JD, Beauchamp J. Fluorescein angiography in central retinal artery occlusion. Arch
Ophthalmol 1967;77:619-29. Crossref

27. Augsburger JJ, Magargal LE. Visual prognosis following treatment of acute central retinal artery obstruction. $\mathrm{Br} \mathrm{J}$ Ophthalmol 1980;64:913-7. Crossref

28. Zhang XZ, Cao JQ. Observations on therapeutic results in 80 cases of central serous retinopathy created with hyperbaric oxygenation. Presented at the 5th Chinese Conference on Hyperbaric Medicine, Fuzhou, China, 26-29 September 1986.

29. Camporesi EM, Bosco G. Mechanisms of action of hyperbaric oxygen therapy. Undersea Hyperb Med 2014;41:247-52.

30. Beard T, Warriner RA, Pascer P, et al. Adverse events during hyperbaric oxygen therapy (HBOT). A retrospective analysis from 25 centers. UHMS Scientific Assembly, Las Vegas, 2005.

31. Hampson N, Atik D. Central nervous system oxygen toxicity during routine hyperbaric oxygen therapy. Undersea Hyperb Med 2003;30:147-53.

32. Leach RM, Rees PJ, Wilmshurst P. Hyperbaric oxygen therapy. BMJ 1998;317:1140-3. Crossref

33. Sheffield PJ, Desautels DA. Hyperbaric and hypobaric chamber fires: a 73-year analysis. Undersea Hyperb Med 1997;24:153-64.

34. Evanger $K$, Haugen $\mathrm{OH}$, Irgens A, Aanderud L, Thorsen E. Ocular refractive changes in patients receiving hyperbaric oxygen administered by oronasal mask or hood. Acta Ophthalmol Scand 2004;82:449-53. crossref

35. Feldelius HC, Jansen EC, Thorn J. Refractive change during hyperbaric oxygen therapy. A clinical trial including ultrasound oculometry. Acta Ophthalmol Scand 2002;80:18890. Crossref

36. Palmquist BM, Philipson B, Barr PO. Nuclear cataract and myopia during hyperbaric oxygen therapy. Br J Ophthalmol 1984;68:113-7. Crossref

37. Tang PH, Engel K, Parke DW 3rd. Early onset of ocular neovascularization after hyperbaric oxygen therapy in a patient with central retinal artery occlusion. Ophthlamol Ther 2016;5:263-9. Crossref

38. Wagner BP, Lindenbaum E, Logue CJ, et al. Rethinking the standard of care for patients with central retinal artery occlusion. Ann Emerg Med 2017;70:S105. Crossref 